\title{
The Emerald Isle turns white: Snow and very low surface temperatures over Ireland during Christmas 2000
}

\section{Edward Graham}

\section{University of Fribourg, Switzerland}

Popular mythology labels Ireland as having a mild and damp climate, with few extremes of temperature throughout the year. For the most part, this classification is justified, especially in the western half of the country where the winter climate is characterised by strong advection of heat energy from the Atlantic (Sweeney 1987/88). Occasionally, however, there are exceptions to this rule, such as in late December 2000 when a series of polar lows and troughs, embedded in a bitterly cold Arctic airstream, brought snow to much of the country. On 27 December 2000, Aldergrove Airport in Northern Ireland recorded its heaviest daily snowfall $(19 \mathrm{~cm})$ since records began there in 1930 (Met Office Press Release on http://www.met office.com/corporate/pressoffice/). Furthermore, weak baroclinic gradients following the polar troughs allowed intense radiational cooling to take place. The result was some of the lowest temperatures on record in Ireland for the month of December, with $-14.0^{\circ} \mathrm{C}$ being recorded at Straide, Co. Mayo, early on the 29th. At the end of a century which has seen an unprecedented rise in global temperatures (Folland et al. 2002), and even more worrying predictions for the coming one (Collins and Senior 2002), it was perhaps fitting that the last week of the climatic millennium should turn the tables somewhat!

In this article, I present a detailed chronology of events during the cold spell. I follow with a closer in-depth analysis of the regions with the lowest temperatures using infrared satellite imagery. I conclude by placing the December 2000 cold spell in a historical context for Ireland.

\section{Sequence of events}

The first three weeks of December 2000 were dominated by a highly zonal pattern of strong south-westerly winds over Ireland, with rainbelts crossing the country at frequent intervals. By the 20th/21st, however, a strong ridge started to build from the
Greenland high (reaching a maximum central pressure of 1040 mbar early on the 23rd). This ridge blocked any further encroachment of Atlantic fronts, which began to occlude and weaken over southern Ireland on the 23rd and 24th. As they finally retreated on the 25 th, a little sleet and hill snow fell in some southern and eastern areas of Ireland, although accumulations were not substantial.

By 25 December (Christmas Day), all of Ireland was under a chilly easterly wind, as strong cold-air advection began to take place from the north-east. By evening, stratocumulus convection from the Irish Sea was great enough to bring the first snow and graupel showers along south-eastern coasts. The following night of the 25th/26th was cold in Northern Ireland (under clear skies), with a minimum of $-6.0^{\circ} \mathrm{C}$ at Castlederg, Co. Tyrone (see Fig. 1 for locations of places mentioned in the text).
Tuesday 26 December, Boxing Day (also known as St. Stephen's Day in the Republic of Ireland), brought more occasional sleet, hail or snow showers to coasts exposed to the north-east breeze. Snow was now lying in hilly areas of the south and east of Ireland, and across parts of Northern Ireland. That evening, winds turned more northerly or variable and decreased, allowing a sharp to severe frost to develop everywhere.

Wednesday 27 December was the first day of widespread snow across Ireland, as a polar low trough pushed south-eastwards across the country. Infrared satellite images available from the University of Dundee (not shown, but available on http://www.sat. dundee.ac.uk) clearly show a marked polar low'comma cloud' centred west of Scotland, indicating that active convection was taking place. Cloud and snow soon spread southeastwards during the morning and afternoon of the 27 th. The precipitation was

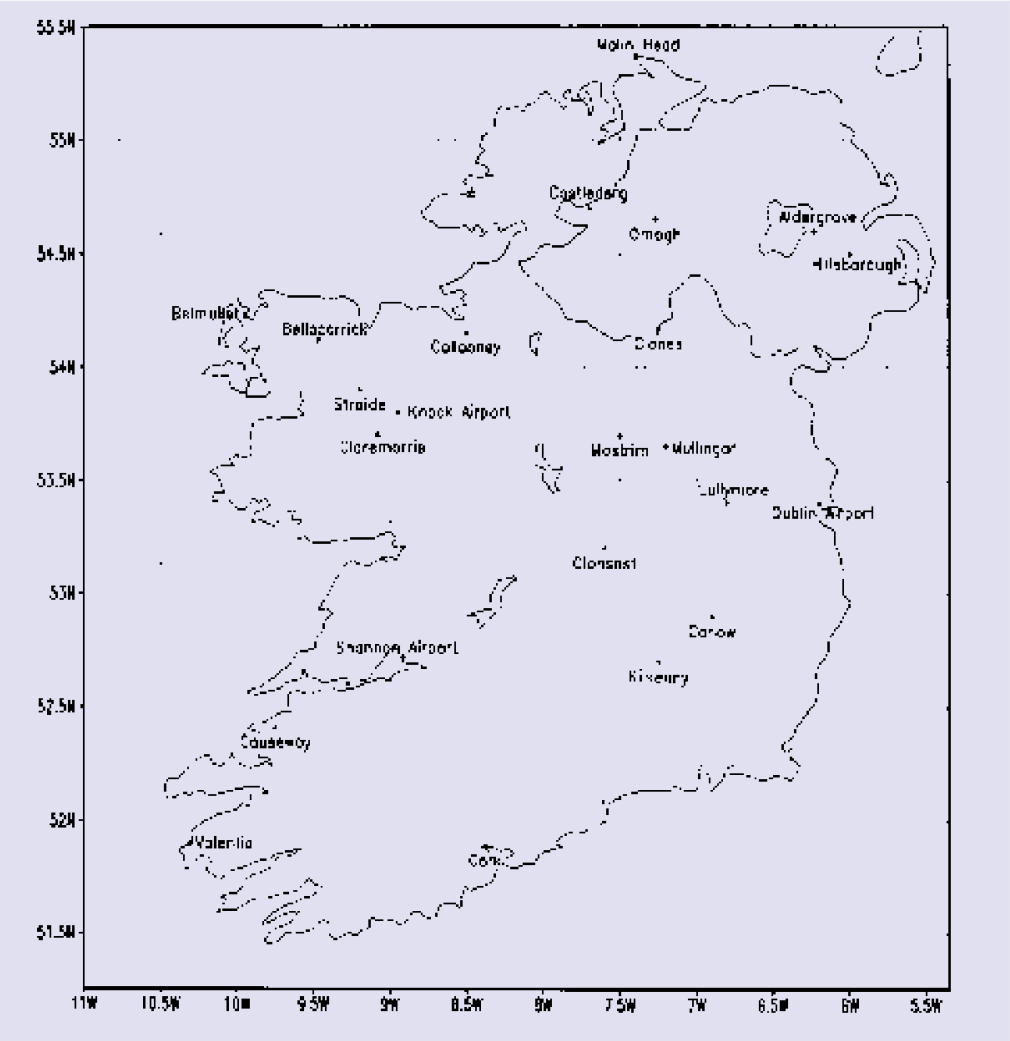

Fig. 1 Ireland, with location of towns and meteorological/climatologicalstations mentioned in the text 


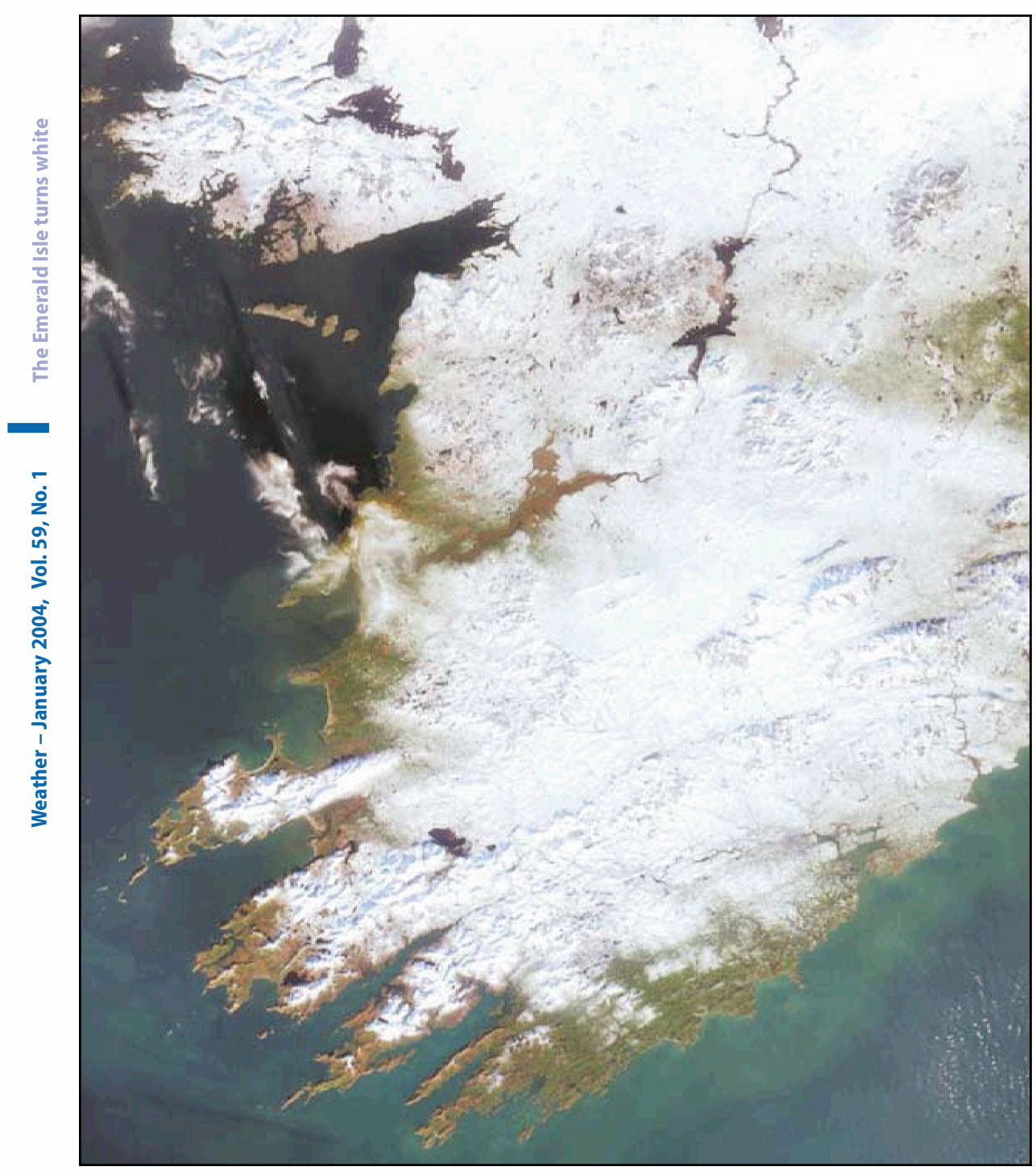

Fig. 2 View of a snowy south-west Ireland on the morning of 29 December 2000. This image was taken from NASA's Terra satellite, using the Multi-angle Imaging SpectroRadiometer (MISR). (Courtesy of NASA/GSFC/JPL, MISR Team.)

heavy and squally at times, leading to significant accumulations of snow by evening inland, with $17 \mathrm{~cm}$ at Knock Airport (altitude $203 \mathrm{~m}$ ) and $11 \mathrm{~cm}$ at Mullingar (108 m), but just $2 \mathrm{~cm}$ at the coastal stations of Belmullet and Malin Head. As much as $7 \mathrm{~cm}$ of snow fell in the hour between 1200 and 1300 GMT at Knock Airport, which is a very high accumulation rate. However, because the warm sources of moisture feeding the polar low were cut off as it moved inland, precipitation intensity decreased quickly as the trough moved south-eastwards, resulting in just $1 \mathrm{~cm}$ of lying snow at Dublin Airport and only a trace at Kilkenny.

The trough finally cleared eastern parts of Ireland during the evening of the 27th, followed by a gusty and cold north-westerly flow. Clearance was delayed across parts of Northern Ireland and nearby Scotland as they were closer to the polar low centre, resulting in Aldergrove's record fall of $19 \mathrm{~cm}$. Meanwhile, heavy snow showers continued pepper the western coasts (Belmullet further increasing its snow depth to $7 \mathrm{~cm}$ ). Many other areas had bright winter sunshine, although freezing fog persisted in inland areas (maximum temperatures reaching only $-6{ }^{\circ} \mathrm{C}$ at Hillsborough). At the same time, a secondary polar low tracked up the Irish Sea and stalled over eastern Ireland during the afternoon and evening, dumping between 5 and $10 \mathrm{~cm}$ of snow in the Dublin area. An area of active winter thunderstorms also moved into south-west Munster during the late evening - a family home was destroyed by lightning at Causeway Village, Co. Kerry. Shannon Airport also reported a thunderstorm (with blowing snow) at 2100 GMT.

The night of the 28th/29th saw snow showers finally retreating to exposed coasts of the north, east and south-east, as radiational cooling became the dominant influence overnight. Very low air temperatures of $-10{ }^{\circ} \mathrm{C}$ occurred widely across the midlands of Ireland, culminating in a value of $-14.0^{\circ} \mathrm{C}$ at Straide. This is the lowest temperature recorded in the Republic of Ireland since $-15.2^{\circ} \mathrm{C}$ was recorded on 12 January 1982 at Clonsast, Co. Offaly. It is just short of the lowest December temperature on record $\left(-14.6^{\circ} \mathrm{C}\right.$ in Carlow on 31 December 1961) and is lower than any recorded during the December 1981 cold spell.

Friday 29 December was a much quieter day countrywide, with bright wintry sunshine in most places. Freezing fog became a problem in the midlands, however, and it began to advect eastwards towards Dublin later in the day. Temperatures varied greatly depending on location; but by and large it was a slightly warmer day than the previous, with maximum temperatures ranging from $-2.2^{\circ} \mathrm{C}$ at Dublin Airport to over $5^{\circ} \mathrm{C}$ at Malin Head and Valentia.

Figure 2 shows the snow-cover situation over south-western Ireland on the morning of 29 December. Inland, snowy areas contrast sharply with the snow-free exposed coasts and islands of the south and southwest. Notice the swaths of lying snow which were deposited by the north-westerly showers of the previous few days.

Similarly to the previous night, the night of the 29th/30th also brought very low temperatures, with Straide and Claremorris (altitude $69 \mathrm{~m}$ ), Co. Mayo, both recording the lowest minimum temperature at $-12.9^{\circ} \mathrm{C}$. The Claremorris value is the station's lowest temperature for any month since February 1969. Amazingly, the nearby station of Knock Airport was reporting just $-2{ }^{\circ} \mathrm{C}$ at the same time, thus making an absolute temperature gradient of $11 \mathrm{deg} C$ for the lowest $130 \mathrm{~m}$ in this part of the country.

After another freezing day on the 30th with widespread low cloud and freezing fog, the cold spell finally ended overnight on 30/31 December as active Atlantic fronts 


\begin{tabular}{|c|c|c|c|}
\hline \multicolumn{4}{|c|}{$\begin{array}{l}\text { Results from the infrared radiative transfer model (similar to the method in Morland et al. 2000) for the } 0000 \text { and } 0600 \text { GMT upper-air soundings } \\
\text { from Hillsborough, } 30 \text { December } 2000\end{array}$} \\
\hline \multirow[b]{2}{*}{ Emissivity* } & \multicolumn{3}{|c|}{ Atmospheric corrections using University of Reading model } \\
\hline & $\begin{array}{l}\text { View angle of } \\
\text { satellite radiometer }\left({ }^{\circ}\right)\end{array}$ & $\begin{array}{l}\text { Correction at }-20.6^{\circ} \mathrm{C} \\
(\mathrm{degC})\end{array}$ & $\begin{array}{l}\text { Correction at } 7.5^{\circ} \mathrm{C} \\
(\mathrm{deg})\end{array}$ \\
\hline \multicolumn{4}{|l|}{0000 GMT } \\
\hline 1.0 & 0 & -0.5 & +0.8 \\
\hline 1.0 & 55.4 & -1.3 & +1.1 \\
\hline \multicolumn{4}{|l|}{0600 GMT } \\
\hline 1.0 & 0 & -1.1 & +0.9 \\
\hline 1.0 & 55.4 & -1.9 & $\begin{array}{r}+1.5 \\
\end{array}$ \\
\hline
\end{tabular}

pushed in quickly from the west. Some snow and local freezing rain fell ahead of the front, but it was generally short-lived and caused minimal disruption.

\section{Satellite image analysis}

In order to deduce areas of extreme low temperatures and observe features that may not be evident from a simple analysis of climatological station reports, I acquired advanced very high resolution (AVHRR) NOAA infrared imagery for the coldest nights (courtesy of the University of Dundee). The procedure used to determine surface temperatures was similar to that employed by Brownscombe and Roach (1984) and Tyrell (1987) during their respective analyses of extremely low surface temperatures during the severe winter of 1981/82 over Britain and Ireland.

In order to obtain surface temperatures from infrared satellite imagery, a calibration table relating brightness radiances to temperature was used (this was provided by the University of Dundee). An atmospheric correction was then calculated for the data. This correction is largely dependent on the atmospheric water vapour content and the view angle of the satellite radiometer. Table 1 lists the results of a University of Reading infrared radiative transfer model (see Morland et al. 2000 for more details), which was run using upper-air data from the 0000 and $0600 \mathrm{GMT}$ soundings at Hillsborough. The results show that, due to the mostly dry atmosphere over Ireland at the time (about $5 \mathrm{~mm}$ equivalent of precipitable water), atmospheric corrections are quite small, and are generally within $\pm 1.5 \mathrm{deg} C$ for the complete range of temperatures seen and for the different satellite view angles (the NOAA satellite scans with a view angle of between 0 and $55.4^{\circ}$ ). This gives greater confidence that the observed surface temperatures are accurate.

The brightness temperature of the snow also depends on the emissivity of the snow surface. In their study of January 1982, Brownscombe and Roach (1984) assumed a value of unity, and this value is probably acceptable for a fresh snow surface. However, some authors (e.g. Kondo and Yamazawa 1986) mention snow emissivities of 0.97 and, if introduced, such a value would cause a further error (estimated) of about $+1.0 \operatorname{deg} C$ to the values presented here.

Given these limitations, Fig. 3 presents a thermal NOAA-12 channel 4 image taken at 0619 GMT on the morning of 30 December.
An atmospheric correction has not been applied to this image. Apart from scattered cumulus clouds around the north coast, skies are clear over the north and west of Ireland. As this is an infrared image, the coldest areas are shown in white. Although lower temperatures may have occurred on the previous morning, this image is the best visually available and provides a wonderful close-up of the features operating on different scales over Ireland at this time. An area

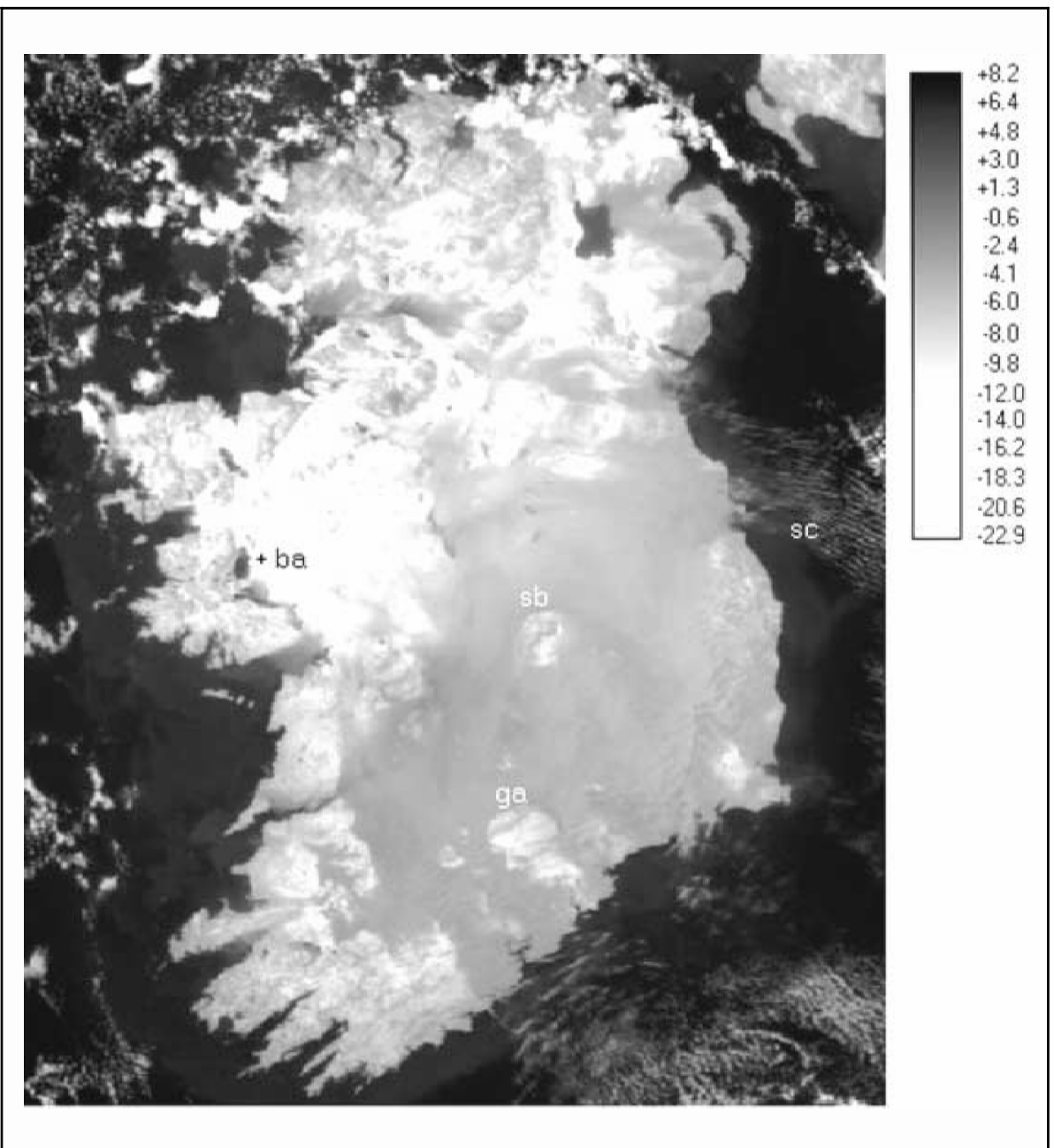

Fig. 3 NOAA-12 channel 4 (infrared) image of Ireland at 0619 GMT on 30 December 2000. Skies are clear, apart from scattered cumulus off the north coast and fog over the south and east of Ireland; ba - Ballinrobe, sb - Slieve Bloom Mountains, ga - Galtee Mountains, sc - stratocumulus streets. Temperature scale in degrees Celsius. 


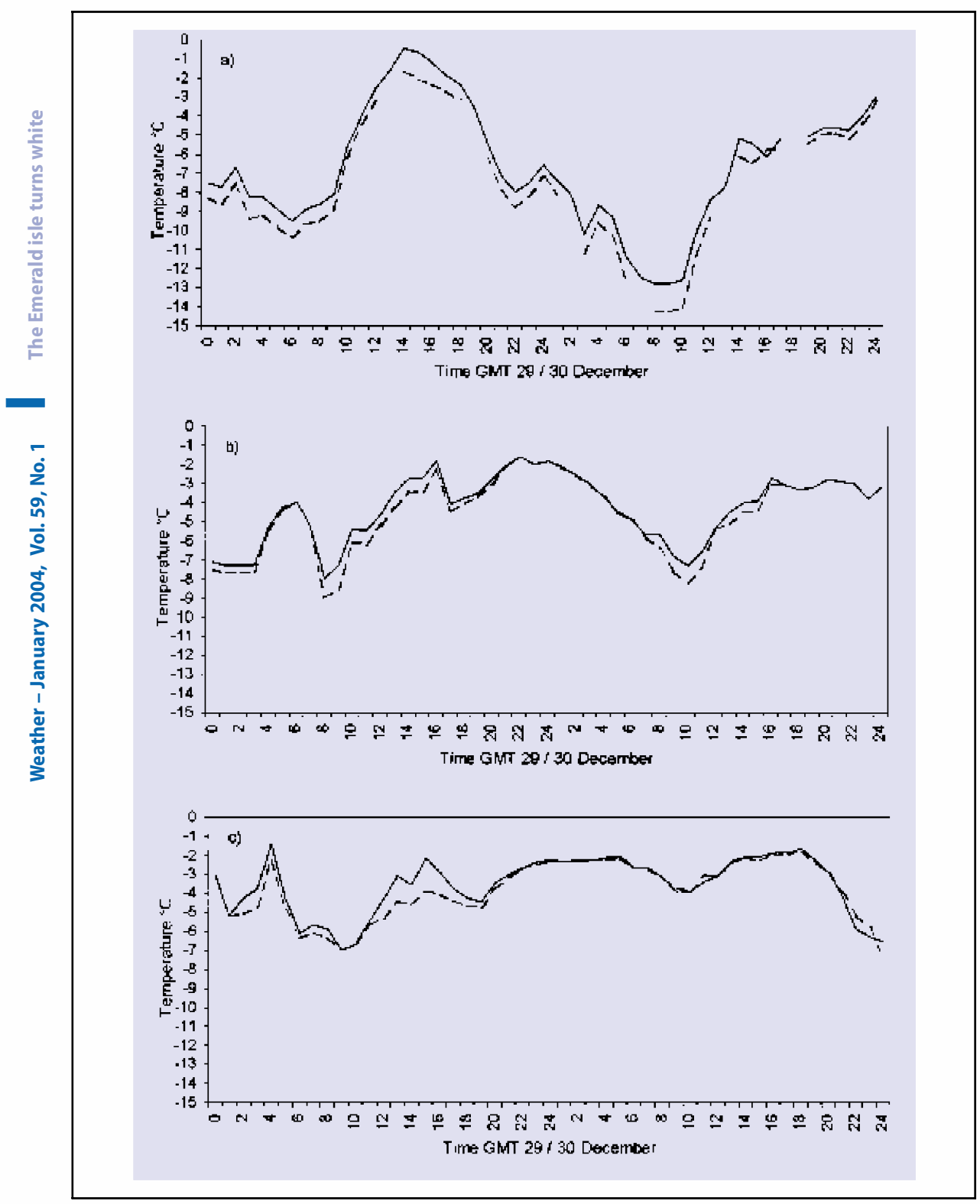

Fig. 4 Air temperatures (solid lines) and dew points (dashed lines) for the 48 hours from 0000 GMT on 29 December to 0000 GMT on 31 December 2000 at (a) Claremorris, (b) Mullingar, and (c) Dublin Airport. Gaps in (a) indicate missing data.

of extremely low surface temperatures covers much of northern and western Ireland, with analysed surface temperatures dipping as low as $-17^{\circ} \mathrm{C}$ in several locations. The cold areas are not uniform, but are strongly controlled by topography, with the warmer mountain ridges of northern and western Ireland standing out clearly against the lowlands and river valleys, where cold dense air has gathered. Notice how the topographical features show a north-east to south-west alignment (as this part of Ireland is a geological continuation of north-west Scotland).

As this image was taken over two hours before dawn, it is perhaps reasonable to assume that the minimum temperatures fell below $-18^{\circ} \mathrm{C}$ later in the morning. Interestingly, one of the most notable cold
Ballinrobe, Co. Mayo (marked as 'ba' on Fig. 3), where a rare winter sport called 'piking' (a type of ice-fishing) takes place on nearby Lough Carra, a lake of approximately $20 \mathrm{~km}^{2}$ in size. The sport involves teams of men running across the frozen lake to try to capture fish from beneath the ice. Prior to December 2000, the last time that this sport took place on Lough Carra was during the very cold month of February 1986. It may be more than coincidence that this unusual Irish pastime occurs in this region of favoured low temperatures, as it is important to realise that it is quite unusual for any body of water in Ireland to freeze to a depth that supports the weight of a human body. This area of intensely low temperatures is also apparent on infrared imagery for the previous night (not shown).

It may be argued that the temperatures we are seeing are just snow surface temperatures, which are not directly related to the air temperature measured in a Stevenson screen environment. Whilst the satellite radiometer is responding to the long-wave radiation from the surface, the air temperature will be closely related to it, especially in areas where the snow has had sufficient time to cool the air immediately above it. Brownscombe and Roach (1984) showed that the coldest areas in their study had grass minimum temperature readings (and hence an indication of the radiation loss) close to the minimum thermometer reading. Also, one might expect snow surface temperatures to be independent of altitude, but this is not the case - Fig. 3 is actually a faithful reflection of topography (in the clear-sky areas), indicating that wide-scale katabatic ponding of dense cold air has occurred. Furthermore, surface temperatures indicated by the satellite imagery are in close agreement with those of the meteorological stations.

In contrast to the very cold north and west of Ireland, Fig. 3 also shows fog and low cloud covering much of the south and east, resulting in much higher and relatively uniform temperatures, generally in the range -4 to $-7^{\circ} \mathrm{C}$ (fog-top temperature). The fog is warmer than the surface, so it therefore appears darker on the infrared image. The fog is flowing gently south-eastwards, and can be seen to 'lap' on to the higher hills and summits, which protrude above the fog (marked as 'sb' and 'ga' in Fig. 3). Stratocumulus convection also occurs where the fog has advected offshore (marked as 'sc').

Why has the fog formed over the south and east of the country, and not in the north and west? In order to answer this question, we need to look at Fig. 4, which shows the trend in air temperature and dew point for Claremorris, Mullingar and Dublin Airport respectively. These three stations provide a sort of 'cross-section' through the centre of Ireland for the 48-hour period commencing at 0000 GMT on 29 December. Claremorris is located in the fog-free area, and therefore shows a diurnal pattern in temperature, with generally strong radiational cooling at night. Mullingar and Dublin Airport are located within the foggy area, and they show some similarities. A snow shower during the early morning of the 29th at Dublin Airport and Mullingar caused the temperature to rise briefly. This was followed by a bright, sunny day with afternoon peaks in temperature to about $-2{ }^{\circ} \mathrm{C}$ and radiational cooling after sunset. The fog commenced close to 2000 GMT at both stations; its formation can be identified as the point where the dew point coincides with the air temperature. It is also coincident with a rise in temperature and dew point. Throughout this time, Dublin Airport was reporting a westerly land- 


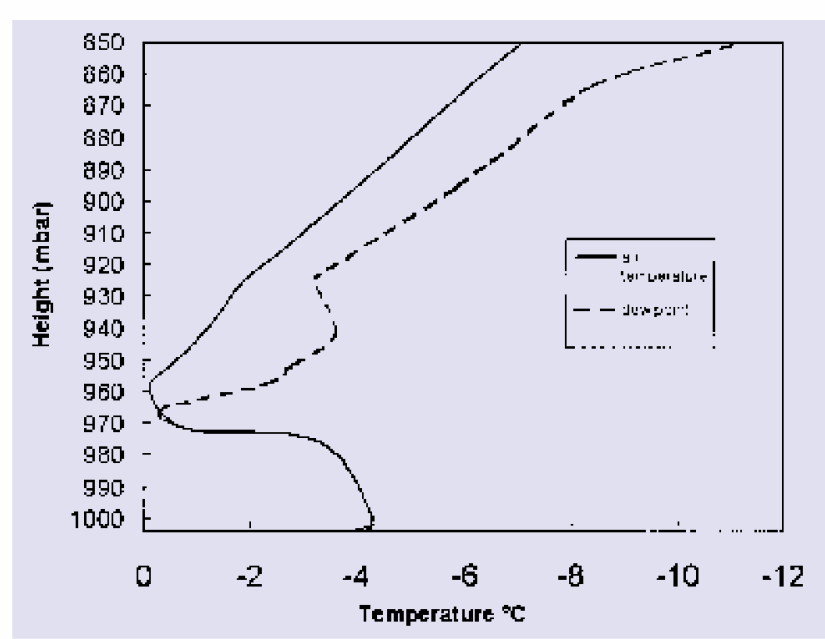

Fig. 5 Upper-air conditions between the surface and 850 mbar at Hillsborough for 0600 GMT on 30 December 2000 (data downloaded from the University of Wyoming, http://weather.uwyo.edu/upperair/sounding.html)

breeze of up to $12 \mathrm{kn}$. Drier air between 0700 and $1000 \mathrm{GMT}$ on the morning of the 30th resulted in colder conditions at Mullingar - these are reflected to a lesser degree at Dublin Airport a few hours later (due to advection from the west). Foggy conditions then continue until the evening of the 30th with a weak diurnal temperature signal. Overall, it is clear that fog formation is related to higher temperatures and moister conditions.

What then is the source of this warmer and moister air? Figure 5 gives some indications, showing the upper-air profile between the surface and $850 \mathrm{mbar}$ at 0600 GMT for Hillsborough. Warmer and moister air (perhaps of marine origin) lies directly above the surface inversion at 970 mbar - with entrainment and mixing of this warmer and moister air probably causing an increase in surface temperatures. Winds at inversion height were as strong as $16 \mathrm{kn}$ from the north-west. It is also likely that increased surface wind speeds (such as the persistent westerly land-breeze at Dublin Airport) helped to aid mixing and turbulence within the boundary layer itself.

\section{The cold snap in a historical setting}

It is worth noting how these extremely low temperatures recorded in December 2000 in Ireland compare in a historical setting. Table 2 (adapted from Rohan 1986) lists the lowest temperatures, from December to March, recorded on the island of Ireland. As can be seen, the lowest temperatures are typically in the range of -15 to $-19^{\circ} \mathrm{C}$, and a value of $-20^{\circ} \mathrm{C}$ has never been recorded. Rohan (1986), however, mentions the probable likelihood that lower temperatures have occurred in frost hollows. Overall, the Christmas 2000 cold spell was an unusual event for Ireland.

\section{Acknowledgements}

I would like to thank the Department of Geography, University of Fribourg, Switzerland, and Environment Canada, Downsview, Canada, for providing the computing facilities which enabled me to research and write this article. A special thank-you must go to Andrew Brooks at the
University of Dundee for providing the highresolution NOAA satellite data. I would also like to thank Kyran Dollard, Niall Brooks and Ben O'Donnell of Met Eireann, Glasnevin, Dublin, who provided the synoptic data for the Republic of Ireland (Northern Ireland data were obtained from Internet sources). I would like to thank my wife, June, for help with the IDRISI software, running the infrared radiative transfer model and proof-reading the text. Finally, I would like to dedicate this paper to the memory of Ignacio Lozano.

\section{References}

Brownscombe, J. L. and Roach, W.T. (1984) Possible causes of the extreme cold during winter 1981-82. Weather, 39, pp. 362-372

Collins, M. and Senior, C. A. (2002) Projections of future climate change. Weather, 57, pp. 283-287

Folland, C. K., Karl, T. R. and Salinger, M. J. (2002) Observed climate variability and change. Weather, 57, pp. 269-278

Kondo, J. and Yamazawa, H. (1986) Measurement of snow surface emissivity. Boundary-Layer Meteorol., 34, pp. 415-416 Morland, J., Grimes, D., Dugdale, G. and Hewison, T. (2000) The estimation of land surface emissivities at 24 to $157 \mathrm{GHz}$ using remotely sensed aircraft data. Remote Sens. Environ., 73, pp. 323-336

Rohan, P. K. (1986) The climate of Ireland, 2nd edition. The Stationery Office in Ireland, Dublin

Sweeney, J. (1987/88) Controls on the climate of Ireland. Geogr. Viewpoint, 16, pp. 60-72

Tyrell, J. (1987) Meteosat 2 imagery of the very low surface temperatures of 12-13 December 1981. Irish Geogr., 16, pp. 79-94

Correspondence to: Mr E. Graham, Department of Geography, University of Fribourg, $1700 \mathrm{CH}$, Fribourg, Switzerland. e-mail:edward.graham@unifr.ch

(c) Royal Meteorological Society, 2004. doi:10.1256/wea.59.03

\begin{tabular}{|c|c|c|c|}
\hline \multicolumn{4}{|c|}{ Lowest temperatures recorded in Ireland by month (adapted from Rohan 1986) } \\
\hline Month & $\begin{array}{l}\text { Temperature } \\
\left({ }^{\circ} \mathrm{C}\right)\end{array}$ & Date & Location \\
\hline Dec. & $\begin{array}{l}-14.6 \\
-14.0\end{array}$ & $\begin{array}{l}31 \text { Dec. } 1961 \\
29 \text { Dec. } 2000\end{array}$ & $\begin{array}{l}\text { Carlow, Co. Carlow } \\
\text { Straide, Co. Mayo }\end{array}$ \\
\hline Jan. & $\begin{array}{l}-19.1 \\
-19.4^{*} \dagger \\
-18.8\end{array}$ & $\begin{array}{l}16 \text { Jan. } 1881 \\
23 \text { Jan. } 1881 \\
2 \text { Jan. } 1979\end{array}$ & $\begin{array}{l}\text { Collooney (Markree Castle), Co. Sligo } \\
\text { Omagh (Edenfel), Co. Tyrone } \\
\text { Lullymore, Co. Kildare }\end{array}$ \\
\hline Feb. & $\begin{array}{l}-17.8^{*} \\
-17.6\end{array}$ & $\begin{array}{l}7 \text { Feb. } 1895 \\
17 \text { Feb. } 1969\end{array}$ & $\begin{array}{l}\text { Mostrim/Edgeworthstown (Currygane House), Co. Longford } \\
\text { Bellacorrick, Co. Mayo }\end{array}$ \\
\hline Mar. & $-17.2^{*}$ & 3 Mar. 1947 & Collooney (Markree Castle), Co. Sligo \\
\hline
\end{tabular}

